\title{
"What should we do?": The Predicament of Practical Reason in Hamlet
}

Eric P. Levy

Résumé : Fondamentalement, ce qui se passe dans Hamlet ne concerne ni l'action ni les antécedents de l'action, mais la mise en cause de la doctrine de l'action rationnelle, donc de la raison pratique. La conséquence de cette critique radicale est de réviser la fin des intentions humaines ainsi que les actes intentionnels par lesquels elles sont réalisées. Au moyen d'un processus analogue à la purgation mentionnée par le revenant de son père, Hamlet développe progressivement une moralité qui transcende le modèle aristotélicien et thomiste.

Through its eponymous protagonist, Hamlet foregrounds the mimetic 1 function of dramatic art: "the purpose of playing ... was and is to hold as 'twere the mirror up to nature."1 But from its opening words, "Who's there?", Hamlet the play deepens the conception of the mirror to which Hamlet the character refers. Whereas an ordinary mirror reflects only that which is given - intact and constituted - outside it, the mimetic mirror in Hamlet represents the process of "transformation" through which the central character "imitated" or reflected forges the meaning of his own identity by questioning the principles on which it is based: "What is a man ... ?" (2.2.5; 3.2 .35 ; 4.4.33). Ironically, when citing the doctrine of the "fault" whereby "particular men" $(1.4 .36,23)$ succumb, inevitably and irreversibly, to their respective flaws, Hamlet invokes the classical notion of character which the play itself, through its representation of him, transcends. In that classical notion, inaugurated by Heraclitus, character unfolds the implications of its own intrinsic structure: "Character for man is destiny."2 But like the Ghost ("What art thou ... ?"), Hamlet himself is defined, not by the clarification of intrinsic structure, but by the problematizing of it: "you would pluck out the heart of my mystery" (3.2.355-56; cf. 1.2.48). 
The "mystery" at the core of Hamlet's identity is not just his alone. At bottom, it is the mystery at the core of personhood or the "single and peculiar life," as the play represents it (3.3.11). As such, Hamlet dramatizes what Ernst Cassirer, in another context, has called "anthropological philosophy": the attempt to achieve a comprehensive understanding of the "humanity" (3.2.35) common to all human individuals, so that the supreme meaning and responsibilities of living might thereby be illumined: "It is not concerned with a single theoretical problem, however general in its scope; here the whole destiny of man is at stake and clamoring for an ultimate decision" (my emphasis). ${ }^{3}$ Precisely this demand for ultimate clarification of purpose resounds in Hamlet's interrogation of the Ghost: "Say why is this? Wherefore? What should we do?" (1.4.56-57, my emphasis). He re-emphasizes this profound urgency when the Ghost beckons him "to a more removed ground": "My fate cries out" $(1.4 .61,83)$. Hamlet's need to know his own defining and consummating purpose is intensified by the melancholy which has already estranged him from the conventional doctrines of purpose which he earlier accepted: "How weary, stale, flat, and unprofitable / Seem to me all the uses of this world!" (1.2.133-34). Yet paradoxically, Hamlet's fate is to understand purpose ("I am constant to my purposes . . " [5.2.197]) only through first deepening his perplexity concerning it.

Indeed, far from resolving the problem of purpose, Hamlet's dialogue with the Ghost soon complicates his uncertainty in this regard, with the result that he questions both his own courage to implement purpose ("Am I a coward?" [2.2.566]) and the Ghost's motives in enunciating purpose: "The spirit I have seen / May be a devil ..." (594-95). In the "To be" soliloquy, Hamlet's perplexity regarding purpose makes an intellectual leap to a different order of concern. Here it is no longer particular purposes (such as those of Hamlet or the Ghost) that are questioned, but the very notion of purpose itself. First, life ("To be") is construed as deprived of any purpose but achieving release or "quietus" (3.1.75) from its own suffering. But this sole remaining purpose is itself problematized by uncertainty concerning the consequences of enactment: "For in that sleep of death what dreams may come, / When we have shuffled off this mortal coil, / Must give us pause

" (66-68). Hence, in the "To be" soliloquy, Hamlet resolves his earlier question: "What should we do?". The answer is that we should do nothing, lest "action" (88) precipitate a situation worse than the one it intends to terminate: "rather bear those ills we have / Than fly to others that we know not of" (81-82). The only reasonable purpose is the forfeit of purpose. There is nothing to be done but restrain "resolution" (84), lest its "consummation" (63) exacerbate the circumstances provoking it. 
The acute conflict, in the "To be" soliloquy, between the urge to action and abstention from action (what Claudius elsewhere refers to as "[d]eliberate pause" [4.3.9]) recurs throughout the play, which often dramatizes the refraining from action at the very moment when the urge to act is most intense: instances include "Pyrrhus' pause" (2.2.483) just before furiously hacking Priam to bits: "For lo, his sword, / Which was declining on the milky head / Of reverend Priam, seem'd i'th'air to stick" (473-75); Hamlet's abstention from murdering Claudius at prayer: "Up, sword, and know thou a more horrid hent" (3.3.88); Hamlet's urging of Gertrude to abstain from conjugal contact with Claudius: "Refrain tonight, / And that shall lend a kind of easiness / To the next abstinence, the next more easy" (3.4.167-69); Claudius' abstention from apprehending Hamlet immediately after the murder of Polonius, "feats, / So crimeful and so capital in nature" (4.7.6-7); Claudius' confidence that Laertes will abstain from assaulting him: "There's such a divinity doth a hedge a king" (4.5.123); and Horatio's abstention from suicide in order to fulfill Hamlet's request to "tell my story" (5.2.354).

As these examples suggest, the conflict between straining toward and refraining from action is central to the play. Indeed, Hamlet's celebrated delay, wherein he craves to "sweep to my revenge" (1.5.31) but remains "laps'd in time and passion" (3.4.107), with "[t]h'important acting" (108) long left undone, epitomizes the centrality of this conflict. In this context, the fundamental question regarding purpose ("What should we do?") becomes far more complex. For it now concerns not only appropriate action, but also the factors problematizing the very notion of purpose. At a fundamental level, as we shall find, what happens in Hamlet concerns neither action only, nor the antecedents of action, but a subjecting of the Christianhumanist doctrine of rational action to a radical critique whose consequence is a reinterpretation of the end or purpose of human "purposes" (5.2.197) and the "purpos'd" acts by which they are fulfilled (237). The immediate upshot of this critique is a re-evaluation of Hamlet's delay. Following Hamlet's own example, conventional explanations tend first to construe delay in terms of deferred or "tardy" (3.4.107) enactment of a purpose already defined, and then to seek reasons for the inaction: "Why yet ... this thing's to do" (4.4.44). ${ }^{4}$ But the critique of the Christian-humanist doctrine of purpose embedded in the play suggests a completely different perspective. Here, delay pertains primarily neither to dilatory enactment of purpose nor to defective or conflicted motivation regarding purpose, but to the process whereby Hamlet deepens the very conception of purpose. 


\section{The Christian-humanist Notion of Practical Reason}

Investigation of these matters must begin with the notion of practical reason. In the Christian-humanist tradition which Hamlet frequently cites, thinking or the exercise of reason is construed as operating differently according to the function of its knowledge. If directed toward the consideration of truth as such, reason is speculative. If directed toward the consideration of action, it is practical. Aquinas succinctly formulates: "For the practical intellect knows truth, just as the speculative, but it directs the known truth to operation." " Gilson expands: "it [reason] is called speculative when it treats of things to be known, and practical when it treats of how its acts are to be done."6 Hence, when praising the "large discourse" (4.4.36) of "godlike reason" (38), Hamlet refers to speculative reason. But when deploring "the pale cast of thought" (3.1.85) which inhibits "action" (88), he refers to practical reason, which, as Grisez indicates, is "the mind working as principle of action, not simply as a recipient of objective reality."7 As John of St. Thomas indicates, unlike that pertaining to speculative reason, the truth of practical reason "lies not in being, but in what ought to be." 8

In the rational schema now under review, the function of practical reason is to direct action by formulating ends or purposes and the means of their achievement. But it can do so only through adherence to its own first principle, which, as Gilson notes, "is that we should desire what is good and avoid what is evil." 9 Without the ability to discern these moral distinctions, practical reason cannot properly perform its function of directing action. As we shall find, the plight of practical reason in Hamlet suggests a fallen world, where moral distinctions are rendered problematic by the rational faculty charged with the task of determining them: "there is nothing either good or bad but thinking makes it so" (2.2.249-50, my emphasis). Indeed, the very name of Hamlet's adversary, Claudius, foregrounds the notion of postlapsarian predicament; for Christian tradition represents man after the Fall as a limping creature (homo claudans), who limps because of the wound or vulneratio of original sin. ${ }^{10}$ In this context, Hamlet's assumed madness becomes profoundly ironic. For it foregrounds the malfunctioning, not of speculative, but of practical reason: the aptitude to conceive purposes and direct them toward realization. Ultimately, as we shall find, the dysfunction of practical reason in Hamlet derives, not only from defects in particular agents with respect to moral discrimination, but from ambiguities in the prevailing morality. Hence, for Hamlet, the physical "consummation" (3.1.63) of action can occur only after he redefines its moral basis, by reforming the distinction between "better, and worse" (3.2.245). 
In the teleological ethics of Christian humanism, it is the function of practical reason to formulate ends and the function of the "will" (3.1.80), thus prompted, to tend or incline toward them in a movement called intention or "intent" (1.2.112). " But this "inclination" (3.3.39) or "inclining" (2.2.275) toward an end presupposes knowledge of that end, and knowledge of an end requires deliberation concerning the means appropriate to realize or achieve it. However, the moral calculus by which the end is known differs from that by which the means is ascertained. Unlike means, ends are simply assumed or conceived, and are not themselves the subject of deliberation, as Aristotle indicates in the Nichomachean Ethics: "Again, wish relates rather to the end, choice to the means; for instance, we wish to be healthy, but we choose the acts which will make us healthy." 12 Aquinas elaborates: "The end is the principle in practical matters, because the nature of the means is to be found in the end. Now the principle cannot be called in question, but must be presupposed in every inquiry. Since therefore counsel [or deliberation] is an inquiry, it is not of the end but only of the means." 13 Once the end is formulated, practical reason must determine, by cognitive deliberation, the means most appropriate to achieve that end. Gilson summarizes this process: "This deliberation (consilium) terminates in a choice (electio) and in the consent (consensus), or approval, given by our will to that choice."14 Thus, in the moral scheme under consideration, action is simply the external terminus of the complex internal process preceding it. Without that process, action is at best "rash" (3.4.27) and at worst "mad" (2.2.92).

\section{The Breakdown of Practical Reason}

Though no Hamlet criticism has yet shown how the play critiques the Christian-humanist doctrine of practical reason, critics have wrangled over that aspect of practical reason which concerns conscience: the ability, not to deliberate morally, but to distinguish between good and evil in particular cases. Indeed, the Elizabethan Puritan, William Perkins, wrote copiously on the subject of conscience as a function of practical reason. ${ }^{15}$ With respect to recent discussion of Hamlet's particular conscience, debate has concerned whether, in his ability to distinguish good from evil, Hamlet is either deficient or overly scrupulous. T. McAlindon presents a representative opinion on the side of deficiency, arguing that Hamlet suffers from moral confusion. ${ }^{16}$ A far more sophisticated inquiry into Hamlet's moral deficiency is developed by John S. Wilks, through application of the notion of "erroneous conscience," which he traces to sixteenth and seventeenth century texts. ${ }^{17}$ In contrast, Catherine Belsey finds that conscience inhibits Hamlet's resolve. ${ }^{18}$ Bertram Joseph unfolds a more technical analysis of the subject, 
by foregrounding the Elizabethan distinction between conscience and scruple. ${ }^{19}$ His views are capably qualified by Carole T. Diffey. ${ }^{20}$

The locus classicus for the breakdown of practical reason in Hamlet is the "To be" soliloquy. Here, the deliberation concerns the means (either "to be" or "not to be") most appropriate to realizing the end (optimization of inner nobility): "whether 'tis nobler in the mind ..." (3.1.57). But, instead of enabling "choice" (3.2.63) or "election" (64) (electio) of appropriate means, Hamlet's deliberation (consilium) rejects both alternatives and renders discrimination between them problematic. Hence, at bottom, the soliloquy concerns, not choosing, but the deconstruction of choice. To choose "to be" is to aggravate revulsion for it and hence to intensify the longing not to be. But to choose "not to be" is to elect an analogous version of the unpredictability afflicting "to be." As formulated in the soliloquy, life (to be) is as much susceptible to unrelenting unpredictability as is the sleep of death (not to be). In one, the cause of unpredictability is fortune; in the other, dreams. There is thus no means by which to achieve the assumed end concerning inner nobility. Indeed, far from optimising the nobility and "sovereignty" (1.4.73) of the mind, both alternatives subvert it: one subjects the mind to dreams over which it has no control; the other subjects the mind to impugning the debilitating effects of its own thinking: "Thus conscience does make cowards of us all" (3.1.83). Moreover, the deliberation constituting the soliloquy concludes, not with the consent (consensus) given by the will to a rational choice, but with an explicit weakening of the will through loss of "resolution" (3.1.84).

The implications of this result are far-reaching. To begin with, according to Christian-humanist ethics, determining nobility or moral value "in the mind" is the definitive function of practical reason - in all instances, not just this one. That is, the mind, through its operation as practical reason, is itself the standard by which moral value is judged. Only practical reason can formulate ends which are truly and unambiguously worthy of intention and ensuing action. Gilson explains: "What is good, for a rational being, is what agrees with its rational nature and, consequently, with reason." 21 Grisez elaborates: "The end is the first principle in matters of action; reason orders to the end; therefore, reason is the principle of action." 22 But in the "To be" soliloquy, the role of practical reason is radically problematized. Reason orders to the end (by formulating the goal of nobility "in the mind"), but subsequently undermines that very end, through impugning the "pale cast of thought" by which reason or the mind operates (3.1.85). To transpose Ophelia's words from another context, the "noble mind is here o'erthrown" (3.1.152), not by loss of reason, but by the very exercise of reason. That is, 
reason forfeits its nobility or pre-eminent value when what it thinks about is the negative effect of its own cogitation. ${ }^{23}$

We reach now the hidden "question" (3.1.56) in the soliloquy. If practical reason is the supreme principle of action, what principle remains to guide or justify action when reason rankly abuses its own reasoning? The undiscovered irony of the soliloquy is that, in this celebrated deliberation on suicide, practical reason simulates "self-slaughter" (1.2.132). The notorious problem of Hamlet's delay becomes more manageable in this context. Inaction now pertains, not to some flaw or factor inhering in Hamlet, but to a questioning of the rational principle which, in virtue of its "sovereignty" (1.5.73) regarding the formulation of ends and means, directs action.

\section{The Blurring of Moral Distinctions}

The predicament of practical reason in the world of the play can be clarified by reference to Laertes, whose correspondence to Hamlet is noted by Hamlet himself: "For by the image of my cause I see / The portraiture of his" (5.2.77-78). In his own approach to revenge, Laertes appears at first to display complete lack of moral discrimination. More precisely, his only principle of discrimination seems to be efficacy. Any "means" (4.5.138) are acceptable so long as they succeed in achieving the intended end - revenge: "Conscience and grace, to the profoundest pit!" (4.5.132). But closer analysis reveals that the act of revenge is here construed as directed, not merely against its victim, but against morality itself. In response to Claudius' query regarding what he would "undertake / To show yourself in deed your father's son" (4.7.122-23), Laertes replies, "To cut his throat i'th church" (125). Here obligation (that-which-should-be-done) entails effacing prohibition (thatwhich-should-not-be-done, in this case epitomized by the sacrilege of murder in the cathedral). But to fulfill that-which-should-be-done by committing that-which-should-not-be-done is to disable practical reason, whose proper functioning presupposes these moral distinctions, as Grisez indicates: "The primary precepts of practical reason . . . concern the things-to-be-done that practical reason naturally grasps as human goods, and the things-to-avoided that are opposed to those goods." 24 Thus, just as, after Polonius' death, Ophelia's words constitute a "document in madness" (4.5.176), so Laertes' revengeful boasts also express madness. But in his case the malfunction of rationality concerns practical, not speculative, reason.

The predicament of practical reason is further evident in the plot which Claudius prepares against Hamlet: "I will work him / To an exploit, now ripe in my device, / Under the which he shall not choose but fall" (4.7.63-65, my emphasis). Here, as in the "To be" soliloquy, the power of choice is neutral- 
ized through elimination of the distinction between available alternatives. Whatever is chosen, the same consequence will result. This plight, of course, mimics the inevitability of fate. But whereas fate, as conventionally construed, determines what will happen regardless of individual choice, here choice itself is constrained with regard to the alternatives available for choosing. That is, as a result of Claudius' unscrupulous "forgery of shapes and tricks" (4.7.88), his victim will be unable to distinguish the right choice from the wrong one. Thus, practical reason is disabled and rendered incapable of proceeding properly from deliberation (consilium) to choice (electio).

\section{The Rectification of Moral Discrimination}

Through a process analogous to the purgation mentioned by the Ghost and the penitent "purging" (3.3.85) attempted by Claudius, Hamlet progressively corrects the tendency to blur moral distinctions, though he never completely rectifies it. Indeed, in the world of the play, the ability to distinguish infallibly between good and evil with respect to action pertains exclusively to divine, and not human, or fallen, judgment. There - and only there - "the action lies / In his true nature" (3.3.61-62). Elsewhere, the accuracy of judgment is compromised by local conditions, such as those disguising or "shuffling" (3.3.61) the moral nature of the object judged or distorting the perspective of the subject judging. This predicament is, of course, epitomized by the apparitions of the Ghost, which foreground both the moral ambiguity of the perceived object ("The spirit I have seen / May be a devil ..." [2.2.594-95] and the instability of the subject perceiving it: Horatio warns that it may "assume some other horrible form / Which might deprive your sovereignty of reason" (1.5.72-73).

Ironically, the Ghost, who is thus associated with the problem of moral confusion, is also the catalyst - one might almost say the inspiration - for Hamlet's own development of moral discrimination. The first indication of this process concerns the stratagem which Hamlet concocts in order to verify the Ghost's testimony regarding the guilt of Claudius: "The play's the thing / Wherein I'll catch the conscience of the King" (2.2.600-1). The resounding success of this tactic leads Hamlet to further enhancement of his moral discrimination while Claudius is praying. In deciding to postpone revenge until a moment when Claudius' comportment has "no relish of salvation in' $t$ " (3.3.92) and thus will assure his relegation to "hell" (95), Hamlet is not, as some critics argue, identifying himself with demonic evil whose sole intent is to secure the damnation of its victim. ${ }^{25}$ Instead, he is affirming that the individual, construed as moral agent, is always redeemable or, to use the philosophical formulation, in potency to redemption, if only his or her 
current actions merit it. That is, the project to ensnare Claudius in evil presupposes his aptitude to do good. Even in the avatar of vice ("Remorseless, treacherous, lecherous, kindless villain!" [2.2.577]), Hamlet recognizes capacity for virtue.

Hamlet's moral discrimination undergoes further focussing in Gertrude's closet. There he initially sees Gertrude only in terms of "habits evil" (3.4.164), whose root and sustaining cause is faulty moral discrimination regarding her two husbands: "what judgment / Would step from this to this?" (3.4.70-71). But in thus devastating Gertrude with awareness of fault ("These words like daggers enter into my ears" [3.4.94]), Hamlet ironically displays a defective discrimination analogous to that which he attributes to her. As Gertrude's terrified query indicates ("Thou wouldst not murder me?" [3.4.20]), he condemns her fault as violently as he does the crime of Claudius. His inability to make accurate moral distinctions indicates a malfunctioning of practical reason, and hence ironizes Gertrude's reference to madness when Hamlet suddenly begins talking to a Ghost whom she cannot see: "Alas, he's mad" (3.4.106).

But, after the Ghost directs his attention to Gertrude's vulnerability ("Conceit in weakest bodies strongest works" [3.4.114]), Hamlet shifts from haranguing her about moral fault to encouraging her toward moral improvement: "O throw away the worser part of it / And live the purer with the other half" (159-60). That is, he is enabled to distinguish good from evil in the same individual - just as he did when Claudius was praying. Yet whereas, when contemplating Claudius, Hamlet exploits the ability to distinguish good from evil (or "worser" from "purer") as a means of maximizing the eventual punishment of his victim, with Gertrude he directs the distinction of "worser" from "purer" toward the end of expediting moral rehabilitation. Moreover, in admonishing Gertrude not to shirk this rehabilitation by claiming that her "vice" is but a figment of his own insanity, Hamlet explicitly links the proper functioning of reason with accurate moral discrimination: "Mother, for the love of grace, / Lay not that flattering unction to your soul, / That not your trespass but my madness speaks" $(3.4 .156,146-48)$.

The enhancement of Hamlet's discrimination during the scene in Gertrude's closet has crucial implications, and therefore warrants elaboration. For here the same means (insistence on recognition of fault) serve different ends: punishment of evil and achievement of good. Before the intrusion of the Ghost, Hamlet's insistence on Gertrude's recognition of her fault is based on the need to punish evil, just as was his immediately preceding decision to defer the assassination of Claudius: "Let me be cruel, not unnatural. / I will speak daggers to her, but use none" (3.2.386). But after 
Hamlet's colloquy with the Ghost, the same insistence on recognition of fault is based on the need to foster moral improvement: "This bad begins, and worse remains behind" (3.4.181).

Nevertheless, the need to punish remains a hallmark of Hamlet's character. Indeed, he identifies himself with punitive function while lugging Polonius' corpse out of Gertrude's closet: "but heaven hath pleas'd it so, I To punish me with this and this with me, / That I must be their scourge and minister" (3.4.175-77). The same need to punish informs his later consignment of Rosencrantz and Guildenstern to instant execution, "[n]ot shrivingtime allow'd" (5.2.47), upon their arrival in England. Fredson Bowers has even argued that the entire problem of delay can be explained in terms of Hamlet's waiting for Providence to provide the opportunity for him as its "minister" (3.4.177) or agent to punish Claudius. ${ }^{26}$ But to reduce Hamlet's motivation to the punishing of evil is to obscure completely the process by which he clarifies the good, and therefore redefines the end or purpose of human action. For, as Gilson indicates, "Morality consists in ordering all human acts in view of the true good, which is the true end." 27

In fact, to the extent that Hamlet does conduct himself as a minister of punishment, he tends to vitiate moral distinctions by meting out to all his victims the same condemnation to death. This confusing of moral distinctions is strikingly implied in his initial response to the inadvertent murder of Polonius: "Thou wretched, rash, intruding fool, farewell. / I took thee for thy better" (3.4.31-32, my emphasis). Here, the term, "better," is significantly ambiguous. On one level, it simply refers to the distinction in social rank between Polonius and the Claudius. But on another, in a scene where the issue of moral "judgment" (3.4.71) is urgently foregrounded, it inevitably suggests a distortion of discrimination whereby Polonius is deemed morally inferior to Claudius. But if there is no accurate discrimination of grades of defect or evil, there can be no accurate discrimination of grades of good. Without certain demarcation of limits, good and evil eventually coincide, engendering the very confusion which Hamlet associates with Gertrude: "for madness would not err / Nor sense to ecstasy was ne'er so thralled / But it reserv'd some quantity of choice / To serve in such a difference" (3.4.73-76).

\section{The Sources of Moral Confusion}

Ultimately, the confusion of moral distinctions in Hamlet pertains, not merely to defects in particular agents with respect to moral discrimination, but to ambiguities in morality itself. As construed in the play, the end of action is favourable "judgment" (3.4.70) of the agent acting. In life, the terms of judgment are "honour" $(5.2 .242,244)$ and "dishonour" $(2.1 .21,27)$; in 
death, "salvation" (5.1.2) and "damnation" (4.5.136). Though the terms of judgment applying respectively in life and death differ, and though in one case judgment is construed as fallible and susceptible to "tricks" (4.5.5; 5.1.98), while in the other (where "the action lies / In his true nature" [3.3.61-62]) it is not, both levels of justice are retributive in that they mete out punishment and reward. But in this context, the moral quality of action becomes problematic. For it is difficult to determine whether the moral act - the act performed in "perfect conscience" (5.2.67) - is, at bottom, opportunistic or truly ethical and therefore (to borrow Kant's phrase) "sundered from all view to any advantage in this or another world." ${ }^{28}$ In other words, it is difficult to determine whether acting morally is a means to an end or an end in itself. ${ }^{29}$

The predicament of morality in Hamlet can be analyzed further. As William James has observed, "morality says that some things are better than other things." 30 But the dominant morality in the world of the play offers no stable criterion of valuation in terms "better, and worse" (3.2.245). Instead of such a criterion, constant in itself independently of its relation to that which is evaluated by it, there is only the imitation of example. More precisely, in applying the "terms of honour" (5.2.242) to a given situation, the individual is judged, not according to an invariable model of moral perfection, but in reference to whatever behavioural exemplars pertain to his or her case. The proper relation between morality and action is therefore reversed. Instead of determining the worth of action according to inviolable principles, morality is made dependent on comparative performance. ${ }^{31}$ In these circumstances, the notion of better and worse is reduced to competition, where each individual attempts to outdo the example set by others: "... 'twould be a sight indeed / If one could match you" (4.7.98-99). Indeed, Hamlet berates Laertes for exactly this motivation: "Dost come here to whine, / To outface me with leaping in her grave?" (5.1.271-72). Earlier, he admonishes the players not to indulge in such competitive exaggeration: "I would have such a fellow whipped for o'erdoing Termagant. It out-Herods Herod" (3.2.13-14).

In this dispensation, exaggeration inevitably distorts or debases the very model it emulates. Moreover, the model itself is not absolute, but varies according to the examples manifesting it. Construed as the best of relevant examples, the model is no better than its superlative instantiation, which, in turn, can eventually be superseded. Indeed, the competitive mentality fostered by this morality demands that the best should be superseded. Hence, the model does not function as a genuine ideal; for as Werner Jaeger notes, "[ $t]$ he essence of an ideal state is that anything different from it is bound to be worse." 32 As already suggested, Hamlet eventually repudiates the com- 
petitive morality. Though at first reproaching himself for not dramatizing his emotions as would a professional player in his situation ("What would he do / Had he the motive and the cue for passion / That I have?" [2.2.554-56]), by the time of the fatal duel Hamlet has overcome concern for competitive performance: "I will win for him and I can; if not, I will gain nothing but my shame and the odd hits" (5.2.173-75).

\section{The Moral Consequences of Meditation on Death}

It is obvious that Hamlet's intervening meditations on death leaven his readiness to disregard competitive distinctions. All the dead are equally dead, and their remains equally malodorous: "And smelt so? Pah!" (5.1.194). But meditation on death affords Hamlet an insight more profound than the recognition that all the paths of glory lead but to the grave. For death not only erases distinctions of relative status among individuals by subjecting all "humanity" (3.2.35) impartially to the same inevitable process of corruption and decomposition. More profoundly, death transforms the end or purpose of human individuality. Whereas the living are defined by the quality of their respective purposes and the constancy of their commitment to them ("I am constant to my purposes" [5.2.197]), the dead (construed in physical terms) can fulfill only the purposes imposed on them, as for example in the "loam" (5.1.203) of Alexander employed in "stopping a bung-hole" (198). In death, the purpose of the individual is no longer to formulate and consummate his own ends, but to be the means to an end beyond himself: "Your fat king and your lean beggar is but variable service - two dishes, but to one table. That's the end" (4.3.23-25); "To what base uses we may return, Horatio!" (5.1.196).

Ironically, Hamlet's insight concerning the status of individuality in death becomes the basis for his climactic anagnorisis about life: "There's a divinity that shapes our ends, / Rough-hew them how we will" (5.2.10-11). Just as the dead, construed as mere matter, are means to ends which exceed their awareness, so the living, construed as agents striving to fulfill their respective purposes, are also means to ends "beyond the reaches" (1.4.56) of their awareness. It is crucial to note how Hamlet here at once invokes and transcends humanist ethics, where, as Walter Jackson Bate indicates, the end of the individual is to "to complete himself: to carry out, to the fullest extent, what is best and most distinctive in him" (original emphasis). ${ }^{33}$ For, according to Hamlet's anagnorisis, the supreme end is completion, not of the individual or part, but of the whole or design in which it participates. In fact, in serving this end, the individual sacrifices the integrity or completion of 
his own identity: "O God, Horatio, what a wounded name, / Things standing thus unknown, shall I leave behind me" (5.2.349-50).

Analysis of Hamlet's spontaneous revision of the "commission" (5.2.26) purveyed by Rosencrantz and Guildenstern illustrates. In reporting his tactics to Horatio, Hamlet describes, in literally dramatic terms, his consternation on discovering Claudius' plot to have him executed on English soil: "Or I could make a prologue to my brains, / They had begun the play" (5.2.30-31, my emphasis). In rewriting the commission, Hamlet simultaneously alters the "play" in which Claudius has trapped him. Ironically, of course, Hamlet is the central character in another play which he cannot change - the one bearing his name. The subsumption, in that larger play, of all the "single and peculiar" (3.3.11) ends of the various characters therein depicted becomes the analogue and exemplum of the "divinity that shapes our ends." For the ends of characters are ultimately subservient to the dramatic and thematic exigencies of the play in which they appear. ${ }^{34}$

Thus, Hamlet's recognition - whether construed religiously or dramatically - is the opposite of his "nutshell" (2.2.254) vision, where the whole or totality has no meaning; for it has shrunk to the volume of the part. An ironic reference to whole and part appears in Rosencrantz' adumbration of Claudius' death: "Never alone / Did the King sigh, but with a general groan" (3.3.22-23). But here the relation of part to whole is reversed. Instead of contributing to completion of the whole, the part now dominates the whole, with catastrophically destructive effect. Perhaps this is the most revealing distinction between Claudius and Hamlet. One, through his "majesty" (3.3.15), exploits the whole as the means to satisfy his own ends. The other, through his readiness, ultimately achieves a view of the whole through which individual ends achieve their supreme "consummation" (3.1.63).

\section{Self-defense vs. Self-transcendence}

Moral discrimination in Hamlet can be probed further. A primary premiss in the world of the play is that the purpose of life is self-defense. Rosencrantz offers a seminal formulation: "The single and peculiar life is bound / With all the strength and armour of the mind / To keep itself from noyance" (3.3.11-13). Indeed, the motif of self-defense ramifies throughout the play, and includes, not only physical protection, but moral and psychological security: a "strict and most observant watch" (1.1.74) is conducted to defend Denmark against possible invasion by young Fortinbras of Norway; Laertes warns Ophelia to remain "Out of the shot and danger of desire" with respect to Hamlet (1.3.35); Hamlet admonishes Ophelia to defend herself against "calumny" (3.1.138) by retiring to a "nunnery" (3.1.141); Claudius plots the 
"present death of Hamlet" (4.3.68) in a vain attempt to assure his own safety. Similarly, Hamlet's project of revenge, undertaken for the sake of his murdered father, is construed as retaliation for an attack mounted during the victim's presumed "secure hour" (1.5.61): "Upon whose property and most dear life / A damn'd defeat was made" (2.2.565-66, my emphasis). Likewise, Fortinbras, lurking near the borders of Denmark, is presumed to be preparing a retaliation for the fatal defeat of his father by the "conqueror" and "vanquisher," Hamlet, Sr. $(1.1 .92,96)$.

The "To be" soliloquy constitutes the reductio ad absurdum of the doctrine that the purpose of life is self-defense. For here, as we have seen, life is conceived as self-defeating damage control, with the individual withdrawn into the fortress of the mind, behind "the pales and forts of reason" (1.4.28), only there to sap and mine unseen confidence in the worth of thinking. The same notion of self-defeating self-defense is applied to the death of Ophelia, who, according to the Grave-digger's interlocutor, has been granted "Christian burial" (5.1.4-5) on the grounds that "she drowned herself in her own defense" (6-7). The futility of self-defense is suggested, too, in the inability of the aged Priam to protect himself against the raging Pyrrhus: "His antique sword, / Rebellious to his arm, lies where it falls" (2.2.465-66).

In the attitude of self-defense, purpose extends no further than the avoidance of or retaliation for defeat. Others are either allies or enemies to be morally distinguished accordingly. Paradoxically, the Ghost who utters the revenge imperative is also associated with a state beyond concern for self-defense: "For it is as the air, invulnerable, / And our vain blows malicious mockery" (1.1.150-51). Indeed, his resignation to suffering for "a certain term" (1.5.10) in purgatorial "fires" (11) obviously suggests a moral purpose higher than self-defense. Similarly, when advised not to follow the Ghost, Hamlet explicitly discards concern for self-defense: "And for my soul, what can it do to that, / Being a thing immortal as itself?" (1.4.66-67).

In Hamlet's eventual recognition regarding end-shaping divinity, individual purpose concerns, not self-defense, but self-transcendence. For, from this perspective, though capable of formulating or rough-hewing particular ends by the operation of practical reason, the individual can neither comprehend nor determine their ultimate object or consequence. Here, as we have seen, the adequation of agent to end or purpose is achieved, not through intention and action only, but through the participation of individual purpose in the totality of purposes which both complete and transcend it. ${ }^{35}$

\section{University of British Columbia}




\section{Notes}

1. William Shakespeare, Hamlet, ed. Harold Jenkins (London: Methuen, 1982), 3.2.20-22. All quotations from Hamlet pertain to this edition, and will henceforth be indicated parenthetically in the text.

2. Heracleitus of Ephesus, Fragment 119, in Ancilla to the Pre-Socratic Philosophers: A Complete Translation of the Fragments in Diels, Fragmente der Vorsokratiker, trans. Kathleen Freeman (Cambridge, MA: Harvard University Press, 1966).

3. Ernst Cassirer, An Essay on Man: An Introduction to a Philosophy of Human Culture (New Haven: Yale University Press, 1944), p. 9.

4. Critical opinion concerning Hamlet's delay can be grouped topically: (a) lack of enthusiasm for an outdated revenge imperative: René Girard, "Hamlet's Dull Revenge," Stanford Literature Review 1 (1984): 159-200; see also Eugene England, "Hamlet Against Revenge," Literature and Belief 7 (1987): 49-62, and Mark Matheson, "Hamlet and "A Matter Tender and Dangerous," Shakespeare Quarterly 46 (1995): 385. Similarly, Janis Lull, "Forgetting Hamlet: The First Quarto and the Folio," in The Hamlet First Published (Q1, 1603): Origin, Form, Intertextualities, ed. James Clayton (Newark: University of Delaware Press, 1992), pp. 137-150, links delay with the conflict between "Honour and Providence," and attributes the latter facter to the growing "demands of Protestant conscience" during the interval between the First Quarto (1603) and the First Folio of 1623 (pp. 145-46). Ronald G. Shafer, "Hamlet: Christian or Humanist?" Studies in the Humanities 1 (1990): 21-35, discusses Hamlet's movement from a "humanistic" standard to a "providentially governed" one. Curtis Brown Watson, Shakespeare and the Renaissance Concept of Honour (1960; rpt. Westport, CT: Greenwood, 1976), also notes the "ethical inconsistency" (p. 131) of the Tudor era, as do Fredson Bowers, Elizabethan Revenge Tragedy, 1587-1642 (Princeton: Princeton University Press, 1940), p. 40, and C. L. Barber, The Idea of Honour in the English Drama: 1591-1700 (Göteborg: Elanders, 1957), p. 331. (b) obligation to wait for Providence to provide an opportunity: Fredson Bowers, Hamlet as Minister and Scourge and Other Studies in Shakespeare and Milton (Charlottesville: University of Virginia Press, 1989) pp. 90-101; Roland Mushat Frye, The Renaissance Hamlet: Issues and Responses in 1600 (Princeton: Princeton University Press, 1984), p. 268; and Irving Ribner, Patterns in Shakespearean Tragedy (London: Methuen, 1960), pp. 65-88. (c) moral ambiguity of the Ghost: Arthur McGee, The Elizabethan Hamlet (New Haven: Yale University Press, 1987), pp. 43-74; Eleanore Prosser, Hamlet and Revenge, 2nd ed. (Stanford: Stanford University Press, 1971), pp. 122-43; Philip Edwards, "Tragic Balance in Hamlet," Shakespeare Survey 36 (1983): 46; Jeffrey Burton Russell, The Prince of Darkness: Radical Evil and the Power of Good in History (Ithaca, NY: Cornell University Press, 1988), pp. 182-85. For relevant bibliographies, see Miriam C. S. C. Joseph, "Hamlet, A Christian Tragedy," Studies in Philology 59 (1962): 119n1, and John S. Wilks, "The Discourse of Reason: Justice and Erroneous Conscience in Hamlet," Shakespeare Studies 18 (1986): 143n10. (d) character flaw: (i) melancholy: A.C. Bradley, Shakespearean Tragedy (1904; London: Macmillan, 1956), pp. 120-128. For a brief bibliography of critics accepting Bradley's conclusion, see Paul N. Siegel, “'Hamlet, Revenge!': The Uses and Abuses of Historical Criticism," Shakespeare Survey 45 (1993): 19n27. For post-Freudian interpretations of melancholy, see Theodore Lidz, Hamlet's Enemy: Madness and Myth in Hamlet (New York: Basic Books, 1975), pp. 195-205; and Arthur Kirsch, "Hamlet's Grief," ELH 48 (1981): 17-36. McGee, pp. 100-1, offers a bibliography of opinions relating Hamlet to Renaissance theories of melancholy. (ii) immaturity or playfulness: Anna K. Nardo, “A Man to Double Business Bound," Shakespeare Quarterly 34 (1983): 189-90; 
Richard A. Lanham, The Motives of Eloquence: Literary Rhetoric in the Renaissance (New Haven: Yale University Press, 1976), p. 137; Charles H. Clifton, "Hamlet Ludens: The Importance of Playing in Hamlet," Selected Papers from the West Virginian Shakespeare and Renaissance Association 6 (1981): 35-41; and G.A. Wilkes, "An Understanding Simple and Unschooled': The 'Immaturity' of Hamlet," Sydney Studies in English 1 (1975-76): 69-75. (iii) excessive intellectualizing: Martin Wiggins, "Hamlet and the Damnation of Claudius," English Review 1.3 (1991): 2-4. (iv) self-consciousness: Daniel W. Ross, "Revising a Map Misread: Hamlet, Romantic Self-Consciousness, and the Roots of Modern Tragedy," in Ronald Dotterer, ed., Shakespeare: Text, Subtext, and Context (Selingrove, PA: Susquehanna University Press, 1989), pp. 107-23. (v) moral attitude toward violence: Bert G. Hornback, "Hamlet's Heroism," Colby Quarterly 30 (1994): 291-97. (e) Oedipal factors: Sigmund Freud, The Interpretation of Dreams, trans. James Strachey (Harmondsworth: Penguin, 1975), pp. 366-68; Emest Jones, Hamlet and Oedipus (1949; New York: Norton, 1976). For a recent neo-Oedipal explication, see Janet Adelman, Suffocating Mothers: Fantasies of Maternal Origin in Shakespeare's Plays: Hamlet to The Tempest (New York: Routledge, 1992), p. 33. (f) denial that delay occurs: J. Philip Brockbank, "Hamlet the Bonesetter," Shakespeare Survey 30 (1977): 109-10; John A.S. Phillips, "Why Does Hamlet Delay? - Hamlet's Subtle Revenge," Anglia: Zeitschrift für englishe Philologie 98 (1980): 34-50.

5. Thomas Aquinas, The Summa Theologica, trans. Fathers of the English Dominican Province (New York: Benziger Brothers, 1952), I, Q. 79, A. 11, ad. 2.

6. Étienne Gilson, The Philosophy of St. Bonaventure, trans. Dom Illtyd Trethowan and F.J. Sheed (New York: Sheed \& Ward, 1938), p. 418. Cf. Jacques Maritain, Art and Scholasticism with Other Essays, trans. J. F. Scanlon (1930; rpt. Freeport, NY: Books for Libraries Press, 1971), p. 5: "The mind as a faculty is a complete self-subsisting whole, but it goes to work very differently according as it has knowledge for the sake of knowing or for the sake of doing."

7. Germain G. Grisez, "The First Principle of Practical Reason: A Commentary on the Summa theologiae, 1-2, Question 94, Article 2," in Aquinas: A Collection of Critical Essays, ed. Anthony Kenny (Garden City, NY: Doubleday, 1969), p. 350.

8. John of St. Thomas, quoted by Maritain, pp. 116-17n14.

9. Étienne Gilson, History of Christian Philosophy in the Middle Ages (New York: Random House, 1955), p. 380.

10. Charles S. Singleton, trans. and ed., The Divine Comedy, by Dante Alighieri, 3 vols., Bollingen Series 80 (Princeton: Princeton University Press, 1970), 1.2.9.

11. Cf. Étienne Gilson, The Christian Philosophy of St. Thomas Aquinas, trans. L. K. Shook (New York: Octagon Books, 1956), p. 260: "the movement by which the will tends toward a certain end is called intention."

12. Aristotle, Ethica Nicomachea, trans. W. D. Ross, in The Basic Works of Aristotle, ed. Richard McKeon (New York: Random House, 1941), III. 2. 1111b26-28.

13. Aquinas, I-II, Q. 14, A 2. resp. Cf. Étienne Gilson, The Philosophy of St. Thomas Aquinas, 3rd rev. and enl. ed., trans. Edward Bullough, ed. G. A. Elrington (1937; rpt. Freeport, NY: Books for Libraries Press, 1971), p. 308: "The intention of the end, being the very principle whence the action started, cannot be called in question. If the end should come to be the object of deliberation, it could not be qua end, but merely in so far as it may be considered in its turn as the means to a further end." 
14. Gilson, History of Christian Philosophy, p. 380. Cf. Gilson, The Christian Philosophy of St. Thomas Aquinas, p. 254: "Deliberation brings us to a point where we observe that several means are capable of bringing us to the end toward which we are tending. Each of these means pleases us, and to the extent that it does, we cleave to it. But of all these means which please us, we at last choose one, and such choice belongs properly to an act of election (electio)."

15. William Perkins, "A Discourse of Conscience," in William Perkins 1558-1602, English Puritanist: His Pioneer Works on Casuistry, ed. Thomas F. Merrill (Nieuwkoop: De Graaf, 1966), pp. 1-78.

16. T. McAlindon, Shakespeare and Decorum (London: Macmillan, 1973), p. 61.

17. Wilks, pp. 117-44.

18. Catherine Belsey, "The Case of Hamlet's Conscience," Studies in Philology 76 (1979): $127-48$.

19. Bertram Joseph, Conscience and the King (London: Chatto \& Windus, 1953), p. 128.

20. Carole T. Diffey, "'Such Large Discourse': The Role of 'Godlike Reason' in Hamlet," Hamlet Studies 11.1-2 (1989): 22-33.

21. Gilson, History of Christian Philosophy, p. 380.

22. Grisez, p. 359.

23. Cf. Dante: "This word 'nobleness' means the perfection in each thing of its proper nature" (Convivio 4.16.4, quoted and trans. Singleton, ed., The Divine Comedy, 1.2.24). According to Aquinas, "the intellect is the highest and noblest of the parts of the soul" (III. Q. 6, A. 2. resp.)

24. Grisez, p. 355.

25. For representative arguments concerning the primacy of evil in the play, see McGee, pp. 43-74, and Jeffrey Burton Russell, The Prince of Darkness: Radical Evil and the Power of Good in History (Ithaca, NY: Cornell University Press, 1988), pp. 182-85.

26. Bowers, Hamlet as Minister and Scourge, pp. 90-101.

27. Gilson, History of Christian Philosophy, p. 715n118.

28. Immanuel Kant, Foundations of the Metaphysics of Morals, trans. Lewis White Beck (Indianapolis: Library of the Liberal Arts, 1959), p. 27n2.

29. Cf. Plato, Gorgias, trans W. D. Woodhead, in Plato: The Collected Dialogues, ed. Edith Hamilton and Huntington Cairns, Bollingen Series 71 (New York: Bollingen, 1961), 499e: "Do you too share our opinion, that the good is the end of all actions and that everything else should be done for its sake, not the good for the sake of everything else?"

30. William James, "The Will To Believe," Essays in Pragmatism, ed. Alburey Castell (New York: Hafner, 1948), p. 105.

31. Cf. Kant, p. 25: "Imitation has no place in moral matters, and examples serve only for encouragement."

32. Werner Jaeger, Paideia: the Ideals of Greek Culture, trans. Gilbert Highet, 3 vols. (New York: Oxford University Press, 1943), 2: 237. Cf. Ernst Cassirer on Plato's Republic: "What he is asking for is not the best but the 'ideal' state" (The Myth of the State [New Haven: Yale University Press, 1946], p. 69). 
33. Walter Jackson Bate, Introduction, Criticism: The Major Texts, ed. Walter Jackson Bate (New York: Harcourt, Brace \& World, 1952), p. 6.

34. For reference to "metatheatrical issues" raised in Hamlet, see Kellie Harrison Bean, "The End Is in the Beginning: Story Telling in Shakespeare, Beckett (and Stoppard)," in Past Crimson, Past Woe: The Shakespeare-Beckett Connection, ed. Anne Marie Drew (New York: Garland, 1993), p. 118. See also the chapter, "Shakespeare's Theatrical Symbolism and Its Function," in Charles R. Forker, Fancy's Images: Contexts, Settings, and Perspectives in Shakespeare and His Contemporaries (Carbondale: Southern Illinois University Press, 1990), pp. 3-17.

35. But according to William R. Morse, Hamlet's anagnorisis entails, not self-transcendence, but self-integration, whereby Hamlet constructs "an understanding of the wholeness of reality out of those elements of his own reality that suggest the possibility of wholeness" ("Shakespearean Self-knowledge: The Synthesizing Imagination and the Limits of Reason," in Drama and Philosophy, vol. 12 of Themes in Drama, ed. James Redmond [Cambridge: Cambridge University Press, 1990], p. 57). 